\title{
INIMOHVRITEGA REVOLUTSIOONISÜNDMUSED EESTI LINNADES 1905. AASTAL
}

\author{
Lauri Kann
}

1905. aasta oli murranguline aeg paljude Vene keisririigis elanud rahvaste ajaloos. Lisaks erakordsele ühiskondlikule liikumisele, mis väljendus muuhulgas poliitilises organiseerumises, streikides ja meeleavaldustes, kaasnes revolutsiooniga ka ulatuslik vägivald. Tollase ühiskonna toimimise seisukohast on oluline küsida, miks ja kuidas kujunesid revolutsioonisündmused vägivaldseks. Selles artiklis võetakse vaatluse alla inimohvritega revolutsioonisündmused Eesti linnades 1905. aastal. Uurimise alt jäävad välja juhtumid, kus inimesed said vigastada, kuid jäid ellu, kuna ei ole võimalik kindlaks teha, kui palju selliseid juhtumeid aset leidis. Võib aga oletada, et paljud revolutsioonisündmuste käigus saadud vigastused ei kajastu üheski ajalooallikas.

1905. aasta vägivald Vene keisririigis lähtus mitmest allikast. Üheks nendest olid revolutsioonilised parteid, kelle jaoks vägivald oli aktsepteeritud võitlusvahend poliitiliste eesmärkide saavutamiseks. Parteid rajasid relvastatud võitlusgruppe, ründasid ametivõime ja kutsusid inimesi üles vägivaldsetele tegudele. ${ }^{1}$ Vägivalla allikaks oli ka riigivõim, kes kasutas relvi olukordades, kus see ei olnud riigi esindajate enesekaitseks ega elanikkonna vahetuks kaitseks vajalik. Nii näiteks tulistati mitmel pool keisririigis rahvakoosolekute pihta ning karistussalgad hukkasid põhjaliku uurimiseta väidetavaid mässajaid. ${ }^{2}$ Kolmandaks vägivalla ilminguks olid murrangulisel ajal aset leidnud masside vägivallapuhangud, mis toimusid tihti ilma selge poliitilise motiivi või mõtestatud eesmärgita. Sellise

\footnotetext{
1 Abraham Ascher, The Revolution of 1905. Russia in Disarray (Stanford: Stanford University Press, 1988), 39, 189, 290; Stanislav Tyutyukin, "U poroga grazhdanskoĭ voinȳ", Pervaya revolyutsiya $v$ Rossii. Vzglyad cherez stoletie, ed. by A. Korelin, S. Tyutyukin (Moskva: Pamyatniki istoricheskoŭ mȳsli, 2005), 352-353; Sergeı̆ Pavlov, Opȳt pervoŭ revolyutsii: Rossiya. 1900-1907 (Moskva: Akademicheskil proekt, 2008), 346.

2 Tyutyukin, "U poroga grazhdanskoĭ voinȳ", 381-382; Orlando Figes, A People's Tragedy: The Russian Revolution 1891-1924 (London: Bodley Head, 2014), 201-202.
} 
vägivalla ilmekas näide on streigiaegsed akende purustamised ning rüüstamised ja süütamised linnades. ${ }^{3}$

Artiklis on esitatud statistika inimohvritega revolutsioonisündmuste kohta Eesti linnades ning võetud vaatluse alla nende sündmuste asjaolud. Revolutsioonisündmuste analüüsi abil on näidatud, et Eestis esines 1905. aastal väga vähe ülestõusnute poolt toime pandud inimohvritega vägivalda, samas kui riigivõimu poolt tapetud inimeste hulk oli märkimisväärne. Inimohvritega revolutsioonisündmustest statistika koostamisel on kasutatud nii 1905. aasta historiograafiat, ametivõimude dokumente kui ka tolleaegset ajakirjandust. Ühtlasi on artiklis näidatud, et vägivaldsed kokkupõrked linnades arenesid korduvalt samalaadsetes situatsioonides. Maapiirkondades toimunu nõuab veel täiendavat uurimist, kuid tuginedes Mihkel Aitsami kogutud andmetele ${ }^{4}$, on võimalik esialgseid järeldusi teha ka maal aset leidnud sündmuste kohta. Igal juhul annab seni teadaolev kinnitust, et ka maapiirkondades olid haruldased juhtumid, kus inimene ülestõusnute käe läbi oma elu kaotas.

Mõnedel keisririigi aladel (Poola, Läti, Venemaa) tapeti palju inimesi nii ülestõusnute kui ka riigivõimu poolt, samas kui teistes piirkondades (Soome, Leedu) oli inimohvreid üldiselt palju vähem. ${ }^{5}$ Laiemalt saab Eestis toimunu näitel demonstreerida, et 1905. aasta riigivõimu vägivalda ei saa põhjendada kui (proportsionaalset) vastutegevust ülestõusnute vägivallale. See küsimus on eriti oluline Baltikumi kontekstis, kuna 1905. aasta revolutsiooni historiograafias on tõstetud esile Balti kubermange kui metsiku ülestõusuga piirkonda ning karistussalkade tegevust on mõnikord esitatud kui vastureaktsiooni siinsetele vägivaldsetele sündmustele. Nii näiteks on Sergei Pavlov oma 1905. aasta revolutsiooni monograafias kirjutanud Baltikumi saadetud karistussalkade kohta, et "võimude vastujulmus [ответная жестокось] ei olnud väiksem" kui ülestõusnute oma. Pavlov on küll eelnevalt kirjeldanud peamiselt ülestõusu Lätis ja maininud tööseisakuid Eestis, kuid ei ole eraldi välja toonud, et Eestis ei olnud ülestõusnute ja karistussalkade ohvrite arv kuidagi võrreldav. ${ }^{6}$ Selles ei ole ka midagi

\footnotetext{
Ascher, The Revolution of 1905. Russia in Disarray, 129-131.

4 Mihkel Aitsam, 1905. aasta revolutsioon ja selle ohvrid Eestis (Lohkva: Greif, 2011).

5 Kuigi võrdlevalt ei ole riigivõimu ja ülestõusnute ohvrite arvu erinevust analüüsitud, on asjaolu, et Soomes ja Leedus oli 1905. aasta vähem vägivaldne kui Poolas, Lätis või Kaukaasias, korduvalt esile toodud. Vt nt Tomas Baikelis, "In Search of the People: The Lithuanian Intelligentsia and the Emergence of Mass Politics in the 1905 Revolution", Revolution in Nordosteuropa, ed. by D. Henning (Wiesbanden: Harrassowitz Verlag, 2011), 105.
}

6 Pavlov, Opȳt pervoй revolyutsii: Rossiya. 190o-1907, 429-431. 
üllatavat, sest kuigi on teada, et Lätis oli ülestõus palju vägivaldsem, ei ole ka Eesti historiograafias võrdlevalt esile toodud, et siin pani peaaegu kogu inimohvritega lõppenud vägivalla toime riigivõim.

Välismaises historiograafias on Eesti ja Läti alale mõnikord viidatud ühtselt Balti kubermangudena, arvestamata omavahelisi suuri erinevusi. Abraham Ascher on 1905. aasta historiograafia üheks mõjukamaks teoseks kujunenud raamatus kirjutanud, et 1905. aasta suvel oli Balti kubermangudes puhkenud mõisnike ja ülestõusnute vahel kodusõda, ${ }^{7}$ kuid Eesti (sh Eestimaa kubermangu) kohta see väide kindlasti ei kehti. Revolutsiooni vägivalda uurinud Anna Geifman on kirjutanud konkreetselt eesti sotsialistide kohta, et nende hulgas olevad "terroristid" olid "alati valvel, kui nende vaatevälja ilmus ükskõik milline reaktsiooni esindaja, keda võis tappa ja paljaks röövida." ${ }^{8}$ Tegelikkuses olid ülestõusnute poolt toime pandud mõrvad Eestis 1905. aastal siiski haruldased. Kui mõningate piirkondade puhul, nagu näiteks Läti, Poola või mitmed Venemaa sisekubermangud, saab tõdeda, et nii riigivõim kui ka ülestõusnud tapsid palju inimesi, siis Eesti ala puhul (nii Eestimaa kubermangus kui ka Liivimaa kubermangu eestikeelses osas) on need arvud äärmuseni tasakaalust väljas.

Artiklis on analüüsitud ka seda, miks esines Eestis ülestõusnute poolt toime pandud vägivalda vähem kui eelnevalt nimetatud piirkondades. Analüüsis on toetatud seisukohta, et üks tõenäoline põhjus peitus siinsetes revolutsioonilistes organisatsioonides. Sotsialistlikud parteid kutsusid ka Eestis üles vägivaldsele võitlusele, kuid nende organisatsioonide võimetus (relvade puudumine, võitlusgruppide organiseerimatus) tingis selle, et Eestis esines ülestõusnute põhjustatud vägivalda vähem. Eestit võrreldakse poliitiliselt suhteliselt sarnases olukorras olnud Lätiga, kus sotsialistlikud organisatsioonid olid tugevamad ning ülestõusnute poolt toime pandud vägivalda esines palju rohkem. Lisaks sellele on artiklis juhitud tähelepanu ka mõningatele senises historiograafias tähelepanuta jäänud asjaoludele, mis võisid Eesti ja Läti sündmuste erinevale arengule mõju avaldada.

\section{Revolutsioon naabrite juures}

1905. aasta revolutsiooni ühed ulatuslikuma ülestõusuga piirkonnad olid Poola ja Läti. ${ }^{9}$ Poolas kutsus Józef Piłsudski juhitud Poola Sotsialistlik Partei

\footnotetext{
7 Ascher, The Revolution of 1905. Russia in Disarray, 160.

8 Anna Geifmani seisukohta selles küsimuses on Eesti lugejale tutvustanud Toomas Karjahärm, 1905. aasta Eestis: sotsialistid ja terroristid (Tallinn: Argo, 2015), 58.

9 Figes, A People's Tragedy, 185.
} 
(Polska Partia Socjalistyczna - PPS) üles Vene keskvõimu vastasele võitlusele eesmärgiga taastada Poola iseseisvus. Piłsudski sõitis Vene-Jaapani sõja ajal koguni ise Jaapanisse ja palus jaapanlastelt raha, relvi ja rahvusvahelist toetust, et Venemaa-vastast ülestõusu korraldada. Sealjuures oli Poola Sotsialistlik Partei juba eelnevalt läinud tülli Venemaa Sotsiaaldemokraatliku Töölisparteiga (VSDTP). Poola partei nõudis, et Vene partei revolutsionäärid hoiaksid oma tegevuses Poolast eemale. ${ }^{10}$ Ühest küljest oli 1905. aasta revolutsioon Poolas võitlus omariikluse taastamiseks, kuid teisest küljest olid sellel ka ülekeisririigilise revolutsiooni ilmingud, nagu tööliste streigivõitlus paremate tingimuste saavutamiseks. ${ }^{11}$ Verised sündmused leidsid aset juba 1904. aasta novembris, kui Varssavis toimus tulevahetus meeleavaldajate ja sõjaväelaste vahel. ${ }^{12}$ Kokkupõrkeid sõjaväe ja ülestõusnute vahel tuli Poolas ette palju, millest kurikuulsaim puhkes 1905. aasta suvel Łódźi tööstuslinnas, mille käigus sõjavägi ja elanikud päevi linnatänavatel lahinguid pidasid..$^{13}$ Nagu mujal keisririigis jäid ka Poolas keskvõimu repressioonid peale ning ülestõusud suruti jõuga maha.

Leedus möödus revolutsioon rahumeelsemalt, kuigi mõned inimohvritega sündmused leidsid ka seal aset. 1905. aasta juulis tulistasid võimud Šiauliai läheduses meeleavaldust, oktoobris juhtus sama Vilniuses. ${ }^{14}$ Poliitiliselt oli 1905. aasta ka Leedu jaoks erakordselt tähtis, kuna sügisel Jonas Basanavičiuse eestvedamisel kogunenud üleleeduline rahvasaadikute kongress - Vilniuse seim - nõudis Leedule autonoomiat ja venestuspoliitika lõpetamist. ${ }^{15}$ Seda, miks Leedus arenesid sündmused rahumeelsemalt kui Lätis, on ajalookirjutuses põhjendatud sellega, et maaküsimus ei olnud leedu talupoegade jaoks niivõrd terav kui lätlaste jaoks, vastuseis poola mõisnikele ei olnud nii suur kui Lätis saksa mõisnikele ning sotsialismiga konkureeris katoliku kiriku poolt pakutav, mis oli leedulaste rahvusliku liikumisega väga tugevalt seotud..$^{16}$

10 Jerzy Zdrada, Historia Polski 1795-1914 (Warszawa: Wydawnictwo Naukowe PWN, 2015), 763-764, 747 .

11 Wiktor Marzec, Rebelia i reakcja. Rewolucja 1905 roku i plebejskie doświadczenie polityczne (Łódź: Wydawnictwo UŁ, 2016), 70.

12 Zdrada, Historia Polski 1795-1914, 764-765.

13 Krzysztof Kowalczyński, Łódź 1905. Kulisy rewolucji (Łódź: Księży Młyn Dom Wydawniczy, 2017), 95-98.

14 Toomas Karjahärm, Jānis Krastiņš, Antanas Tyla, Revolyutsiya 1905-1907 godov v Pribaltike (Tallinn, 1981), 43, 50.

15 Bronislovas Genzelis, The restitution of Lithuania's statehood (Vilnius: Lithuanian National Museum, 2007), 65-67.

16 James D. White, "The revolution in the Baltic provinces", The Russian Revolution of 1905. Centenary percpectives, ed. by J. Smele, A. Heywood (New York: Routledge, 2012), 74-75. 
Soomes ei olnud Poola või Lätiga võrreldavat vägivaldset ülestõusu, kuid murrangulised poliitilised sündmused arenesid ka seal. Soome novembristreik $^{17}$ ühendas paljusid poliitilisi jõude ja haaras suure osa ühiskonnast. Ulatuslik väljaastumine sundis keisrivõimu taastama Soome autonoomia, mida keskvõim oli 19. sajandi lõpus asunud likvideerima. ${ }^{18}$ Sealjuures toimus aastatel 1904-08 Soomes mitmeid atentaate, mis oli Soome poliitilisele elule varasemalt võõras. 1904. aastal tapeti kindralkuberner Nikolai Bobrikov, 1905. aastal toimus koguni viis atentaati. Antti Kujala hinnangul oli kõigi nende atentaatide taga Soome Aktiivne Vastupanupartei (Suomen Aktiivinen Vastustuspuolue) või Soome sotsialistlik partei. ${ }^{19}$

Lätis hukkusid nii riigivõimu kui ka ülestõusnute tegevuse tagajärjel sajad inimesed. ${ }^{20}$ Riias võttis politseiametnike ründamine niivõrd ulatuslikud mõõtmed, et paljud politseinikud panid eluohtliku ameti lihtsalt maha. ${ }^{21}$ Detsembri alguses kirjutas ajutine kindralkuberner Vassili Sollogub, et Riias tapavad revolutsionäärid igal ööl politseinikke ja kordnikke. ${ }^{22}$ Ametlikel andmetel tapeti 1905. aastal ja 1906. aasta alguses Riias 122 korrakaitsjat. ${ }^{23}$ Revolutsiooni kõrgajal 1905. aasta sügisel võtsid ülestõusnud Lätis enda kontrolli alla terveid linnu ning lahingutes võimudega osales tuhandeid inimesi. Kui ülestõusnutel õnnestus sõjavägi Tukumsi linnast välja ajada, siis linna tagasivallutamisel pommitas sõjavägi linna koguni kahuritega. Verised lahingud leidsid Lätis aset ka mitmel pool mujal. ${ }^{24}$ Kuna suur osa ülestõusnute tegevusest oli suunatud baltisaksa mõisnike vastu ning baltisakslased olid tihedalt seotud karistusoperatsioonidega, siis on Läti ajalookirjutuses 1905. aasta lõpul maapiirkondades toimunud sündmusi nimetatud baltisaksa aadli ja läti talupoegkonna vaheliseks kodusõjaks. ${ }^{25}$

\footnotetext{
17 Soome ajalookirjutuses novembristreik, tollal Vene keisririigis kehtinud Juliuse kalendri järgi toimus streik oktoobris.

18 Viljo Rasila, Istoriya Finlyandii (Petrozavodsk: Izdatel'stvo Petrozavodskovo universiteta, 1996), 106-109.

19 Antti Kujala, "Finland in 1905. The political and social history of the Revolution", The Russian Revolution of 1905. Centenary percpectives, ed. by J. Smele, A. Heywood (New York: Routledge, 2012), 87.

20 Toomas Karjahärm, "Sotsialistid ja terroristid 1905. aasta revolutsioonis II", Tuna, 3 (2015), 46-50.

${ }^{21}$ Līga Lapa, "Kaujinieku kustība no pirmsākumiem līdz 1905. gada otrajai pusei", 1905. gads Latvijā: 100. Pētījumi un starptautiskas konferences materiāli, 2005. gada 11.-12. janvāris, Rìga (Rīga: Latvijas vēstures institūta apgāds, 2006), 408.

22 Pavlov, Opȳt pervol̆ revolyutsii: Rossiya. 1900-1907, 429; Tyutyukin, "U poroga grazhdanskoŭ voinȳ", $380-381$.

23 Karjahärm, "Sotsialistid ja terroristid 1905. aasta revolutsioonis II", 46.

24 Pavlov, Opȳt pervoŭ revolyutsii: Rossiya. 1900-1907, 430.

25 Geschichte Lettlands. 20. Jahrhundert, ed. by D. Bleiere (Riga: Jumava, 2008), 63.
} 
Ka Eestis põletati 1905. aastal mõisaid ja hõivati ühiskondlikke hooneid, ${ }^{26}$ kuid selliste juhtumite mastaabid olid väiksemad kui lõunanaabrite juures. Baltisaksa ajaloolane Astaf von Transehe-Roseneck kirjutas juba oma 1907. aastal ilmunud raamatus "Die Lettische Revolution", et kui Eestis tapeti 1905. aastal üks sakslane, siis Lätis tapeti neid $40 .{ }^{27}$ Läti tööstusettevõtetes toimus aasta jooksul palju rünnakuid administratsiooni liikmete vastu, sealjuures tuli ette juhtumeid, kus vabriku meister maha lasti. ${ }^{28} \mathrm{Ka}$ Eestis esines tööliste kallaletunge meistritele, ${ }^{29}$ kuid teadaolevalt mitte ühtegi surmajuhtumit.

Revolutsiooni suurem vägivaldsus Lätis on eriti tähelepanuväärne, võttes arvesse asjaolu, et ühiskonna poliitiline aktiivsus oli 1905. aastal väga kõrge ka Eestis..$^{30}$ Lisaks seninägematult ulatuslikele streikidele (sh esimestele poliitilistele streikidele) kirjutati tuhandeid kaebekirju, peeti meeleavaldusi, asutati sotsiaaldemokraatlik partei ning korraldati nii kohalikke koosolekuid kui ka ülemaaline kongress. ${ }^{31}$ Nagu juba eelnevalt mainitud, oli revolutsioon Lätis vägivaldsem justnimelt ülestõusnute tegevuse poolest. Riigivõim tõstis relvad elanike vastu korduvalt nii Lätis kui ka Eestis. Nii Riias kui ka Tallinnas leidsid 1905. aastal aset traagilised sündmused, kui sõjavägi meeleavalduse pihta tule avas ja ligi sada inimest tappis. ${ }^{32}$ Riigivõimu andmetel tapsid karistussalgad Lätis ja Eestis üle 600 inimese ja revolutsiooni tõttu moodustatud sõjakohtud aastatel 1905-08 veel üle 600 inimese. ${ }^{33}$ Kuigi Lätis tapsid võimud rohkem inimesi kui Eestis, küündib ohvrite arv ka siin sadadesse.

\section{Inimohvritega sündmused Eestis}

Alljärgnevas tabelis on esitatud inimohvritega revolutsioonisündmused Eesti linnades. Andmete saamiseks on kasutatud nii historiograafiat, ${ }^{34}$

\footnotetext{
26 Toomas Karjahärm, "1905. aasta revolutsioon”, Eesti ajalugu V. Pärisorjuse kaotamisest Vabadussõjani, peatoim S. Vahtre (Lohkva: Greif, 2010), 359.

27 Toivo Ü. Raun, "Vägivald ja revolutsiooniline aktiivsus Balti provintsides 1905. aastal", Vikerkaar, 7-8 (2015), 102-103.

28 Lapa, "Kaujinieku kustība no pirmsākumiem līdz 1905. gada otrajai pusei”, 390.

29 Karjahärm, "Sotsialistid ja terroristid 1905. aasta revolutsioonis II", 49.

30 Raun, "Vägivald ja revolutsiooniline aktiivsus Balti provintsides 1905. aastal”, 110.

31 Karjahärm, "1905. aasta revolutsioon", 354-359.

32 Riias 13. jaanuar 1905, Tallinnas 16. oktoober 1905.

33 Toomas Karjahärm, Ida ja lääne vahel. Eesti-vene suhted 1850-1917 (Tallinn: Eesti Entsüklopeediakirjastus 1998), 117, 121.

34 Eesti 1905. aasta historiograafia on ulatuslik. Vägivaldsete kokkupõrgete andmete seisukohast on eriti olulised: Karjahärm, "Sotsialistid ja terroristid 1905. aasta revolutsioonis II”; Aitsam, 1905. aasta revolutsioon ja selle ohvrid Eestis; Hillar Saha, “1905.
} 
ametivõimude dokumente ${ }^{35}$ kui ka ajalehtede Eesti Postimees, Postimees ja Uudised 1905. aasta numbreid. 1905. aasta ajalehtedes on revolutsioonisündmuste kirjeldamisele pööratud suhteliselt palju tähelepanu. Inimohvritest on ajalehtedes korduvalt teada antud ning ei ole alust arvata, et oleks hoidutud avalikkusele sellekohase informatsiooni edastamisest. Tabelist on välja jäetud ajakirjanduses kajastatud inimohvritega sündmused, mis ei olnud revolutsioonisündmustega seotud (õnnetusjuhtumid, inimeste omavahelised tülid jne). Mõningatel juhtudel on ajalehtedes teatatud sündmusest, kus inimene on raskelt viga saanud, kuid tema edasise saatuse kohta andmed puuduvad.

Ka ametivõimude dokumendid (ettekanded toimunud sündmustest, prokuratuuri raportid jne) on olulised revolutsioonisündmusi kajastavad allikad. Arvestada tuleb sellega, et kui ametivõimud ei pruukinud ka olla alati teadlikud sellest, kui mõni meeleavaldusel osalenud inimene surmavalt haavata sai, siis kindlasti olid võimudel andmed selle kohta, kui keegi nende alluvatest elu kaotas. Ülematele edastati andmeid ka vigastatud sõjaväelaste ja politseinike kohta.

Historiograafias ei ole küll võrdlevalt esile toodud, kui palju inimesi tapsid ülestõusnud ning kui palju võimud, kuid inimohvritega revolutsioonisündmusi on neis siiski kajastatud. Seetõttu on nii statistika koostamisel kui ka sündmuste asjaolude selgitamisel pööratud põhjalikult tähelepanu ka historiograafiale. Kuigi on võimalik, et mõni inimohvritega revolutsioonisündmus kasutatud allikates ei kajastu, ilmneb nii ajakirjandusest, historiograafiast kui ka ametivõimude dokumentidest siiski selgesti asjaolu, et peaaegu kogu inimelu kaotustega vägivalla pani Eestis toime riigivõim. Inimohvritega revolutsioonisündmusi Eesti linnades on 1905. aastast teada viis.

Tabel 1. Inimohvritega revolutsioonisündmused Eesti linnades 1905. aastal.

\begin{tabular}{|l|c|c|}
\hline Sündmuse aeg ja koht & $\begin{array}{c}\text { Võimude poolt tape- } \\
\text { tud inimesed }\end{array}$ & $\begin{array}{c}\text { Ülestõusnute poolt } \\
\text { tapetud inimesed }\end{array}$ \\
\hline 14. jaanuar, Tallinn & 2 & - \\
\hline 15. jaanuar, Tallinn & 3 & - \\
\hline 16. oktoober, Tallinn & 95 & - \\
\hline
\end{tabular}

aasta oktoobri veretöö ohvrite nimekiri”, ENSV TA Toimetised, 2 (1955), 321-325; “Tallinna Uuel turul tapetud ja haavata saanud inimeste nimekiri”, Tallinna ajaloo lugemik. Dokumente 13.-20. sajandini, koost T. Kala, J. Kreem, L. Kõiv, K. Mäeorg, A. Mänd, T. Parts (Tallinn: Tallinna Linnaarhiiv, 2015), 425-432.

35 Revolyutsiya 1905-1907 v Estonii. Sborbik dokumentov i materialov (Tallinn: Estonskoe gosudarstvennoe izdatel'stvo, 1955). 


\begin{tabular}{|l|c|c|}
\hline Sündmuse aeg ja koht & $\begin{array}{c}\text { Võimude poolt tape- } \\
\text { tud inimesed }\end{array}$ & $\begin{array}{c}\text { Ülestõusnute poolt } \\
\text { tapetud inimesed }\end{array}$ \\
\hline 17. oktoobril, Tartu & 1 & - \\
\hline 1. november, Narva & 1 & - \\
\hline Kokku & 102 & 0 \\
\hline
\end{tabular}

Riigivõim tappis üle saja inimese ning ülestõusnud teadaolevalt mitte ühtegi. Eesti linnades lõppesid kõige traagilisemalt meeleavaldajate või streikivate tööliste ja sõjaväelaste kokkupõrked. Ühendavaks asjaoluks on ka see, et kõik juhtumid leidsid aset paljusid ettevõtteid hõlmanud streigi tingimustes. Kõigile juhtumitele eelnesid väiksemat või suuremat sorti korrarikkumised. Enne kui peatume detailsemalt linnades aset leidnud sündmuste asjaoludel, pöörame tähelepanu ka sellele, mida on Mihkel Aitsami andmetele tuginedes teada maapiirkondades toimunu kohta.

Tabel 2. Inimohvritega revolutsioonisündmused Eesti maapiirkondades kuni 1905. aasta detsembri keskpaigani (Mihkel Aitsami andmete põhjal).

\begin{tabular}{|l|c|c|}
\hline Sündmuse aeg ja koht & $\begin{array}{c}\text { Sõjaväelaste, mõisnike } \\
\text { või mõisnike poolel } \\
\text { olnute poolt tapetud } \\
\text { inimesed }\end{array}$ & $\begin{array}{c}\text { Ülestõusnute poolt } \\
\text { tapetud inimesed }\end{array}$ \\
\hline $\begin{array}{l}\text { 28. november, Koda- } \\
\text { vere }\end{array}$ & 1 & - \\
\hline 28. november, Karja & 3 & - \\
\hline 9./10. detsember, Tapa & 1 & - \\
\hline 13. detsember, Hageri & & - \\
\hline 14. detsember, Juuru & 1 & - \\
\hline 14. detsember, Rapla & 2 & - \\
\hline 14. detsember, Hageri & 4 & - \\
\hline 15. detsember, Hageri & 7 & 1 \\
\hline Kokku & 19 & 1 \\
\hline
\end{tabular}

Tabelis on esitatud andmed kuni 1905. aasta detsembri keskpaigani, mil Eesti alale saabusid karistussalgad. Karistussalkade ulatusliku vägivalla aega tuleks vaadelda omaette perioodina, kuna selle kohta enam-vähem kindlate andmete saamine nõuab veel omaette uurimist. Mihkel Aitsami 
uurimuse "1905. aasta revolutsioon ja selle ohvrid Eestis" andmetel toimus Eesti maapiirkondades kuni 15. detsembrini kaheksa inimohvritega revolutsioonisündmust. Neist neljal juhul leidis aset talupoegade kokkupõrge tragunitega (14. detsembril Juuru, Rapla ja Hageri kihelkondades ning järgmisel päeval samuti Hageris) ning kahel juhul tulistati mõisa juurde nõudmisi esitama tulnud talupoegi (28. novembril Alatskivil Kodavere kihelkonnas ja Karja kihelkonnas). Tapal toimunud kokkupõrkes hukkus sõjaväelaste käe läbi kõrvalseisja. 13. detsembril haavasid mõisa rüüstajad surmavalt Salutaguse mõisavalvurit. ${ }^{36}$

Eriti maapiirkondade puhul on tõenäoline, et mõni aset leidnud sündmus tabelis ei kajastu. Siiski on ilmne, et ülestõusnute põhjustatud inimelu kaotustega vägivald oli Eestis 1905. aastal ka maal harvaesinev. Kindlad võime olla revolutsioonisündmustes hukkunud mõisnike arvus, kuna sellised juhtumid pälvisid kindlasti tähelepanu ja kajastamist. 1905. aasta revolutsioonisündmustes hukkus Eestis üks saksa mõisnik. 20. detsembril tulistasid Harjumaal asuva Peningi mõisa rüüstajad surnuks mõisa omaniku Arthur von Baranoff. ${ }^{37}$ Sellised juhtumid jäid haruldaseks ka hiljem. Suurt avalikku tähelepanu pälvis parun Otto von Budbergi tapmine segastel asjaoludel 1907. aastal. ${ }^{38}$

Seevastu 1905. aasta detsembri keskpaigas Eesti alale saabunud karistussalkade tegevuse tagajärjel hukkus sadu inimesi. Läti sotsiaaldemokraadist duumasaadik Janis Ozols esitas 1907. aastal riigiduumas arupärimise karistussalkade tegevuse kohta Eesti ja Läti alal. Esitatud dokumendi andmetel tapsid karistussalgad Eesti alal ilma kohtuotsuseta 188 inimest. ${ }^{39}$ Baltimaade ajutise kindralkuberneri andmetel tapeti karistussalkade poolt 1905.-07. aastal Eesti ja Läti alal üle 600 inimese ning sõjakohtute otsusel aastatel 1905-08 samuti üle 600 inimese. Sealjuures on ilmne, et karistussalkade ja sõjaväljakohtute poolt toime pandud karistusaktsioonid olid sisulisest õigusemõistmisest väga kaugel. Sõjaväljakohtud pidid surmaotsuse langetama 48 tunni jooksul ning sellele järgnenud 48 tunni jooksul selle täide viima. Keiser keelas esitada armuandmispalveid ning karistussalkasid hoiatati, et liigse karmuse eest ei karistata, küll aga liigse leebuse eest. Hiljem keelati algatada uurimisi karistussalkade võimu kuritarvituste suhtes. ${ }^{40}$

\footnotetext{
36 Aitsam, 1905. aasta revolutsioon ja selle ohvrid Eestis, 119, 333, 337, 356, 358.

$37 \quad$ Ibid., 127.

38 Karjahärm, "Sotsialistid ja terroristid 1905. aasta revolutsioonis II", 50-51.

39 Karjahärm, Ida ja lääne vahel. Eesti-vene suhted 1850-1917, 118.

40 Ibid., 115-121.
} 


\section{Sündmuste asjaolud}

Nagu eelnevalt mainitud, leidsid kõik inimohvritega kokkupõrked linnades aset streigi tingimustes. Üheks peamiseks tööliste ja sõjaväelaste kokkupõrke ajendiks oli olukord, kus üldstreigi ajal mõnes ettevõttes töö jätkus ning streikivad töölised saabusid linna teistest ettevõtetest ja sundisid tööd lõpetama. Sellistes olukordades saadeti sõjaväelasi streikivate tööliste ja töötava ettevõtte vahele, mis lõi äärmiselt ohtliku olukorra. 1905. aasta revolutsiooni esimesed ohvrid Eestis tulenesidki sellise iseloomuga kokkupõrgetest Tallinnas.

Peterburi verise pühapäeva mõjul algas 12. jaanuaril 1905 üldstreik ka Tallinnas. Streigi esimesel õhtul leidis linna peal aset lõhkumisi, muuhulgas süüdati Kuke tänaval põlema üks maja ${ }^{41} 14$. jaanuaril üritas tööliste rongkäik Tallinnas panna seisma gaasivabriku ehk gaasijaama tööd, kuid see ei õnnestunud, kuna vabrikut valvanud sõjaväelased, politseinikud ja vabriku ametnikud veensid töölisi taganema. ${ }^{42}$ Gaasijaama kaitsmine tööseisaku eest oli võimudele äärmiselt oluline ka seetõttu, et sealt varustati äreval ja pimedal ajal linna tänavalaternaid. Pärast ebaõnnestunud katset gaasijaama tungida, liikusid töölised Tallinna sadamasse, kus sündmused arenesid märksa kurvemalt. Eestimaa kuberner Aleksei Bellegarde kirjeldas siseministrile, et kokkupõrge tekkis, kui rahvahulk oli üritanud lõpetada sadamas elevaatori tööd ning sõjavägi neid takistas. ${ }^{43}$ Eesti Postimehes kirjutati, et elevaatori ees "jällegi soldatid püssidega seisivad ja rahvast edasi minna ei lasknud. Kahjuks tuli aga siin kokkupõrkamine sõjaväe ja rahva hulga vahel, mille järeldus see oli, et üks inimene püssitiku läbi surma ja kolm inimest haavata saiwad." ${ }^{\prime 4}$ Mihkel Aitsami käsitluse järgi olevat sõjaväelastele antud Tallinna garnisoniülema kindral Pavel Voronovi poolt korraldus kohe inimeste pihta lasta, kuid kohapealsed ohvitserid asusid korraldama rahvahulga püssipäradega laialiajamist. "Tekkis rüselemine ja keegi sõdur lõi selja tagant noore töölise Aleksander Kasmanni rinnust läbi, nii et too samasse surnult maha langes. Seda nähes hüppasid mõned soldatite lähenemisel üle sadamakai merre. Kustas Poll sai raskesti haavata ja suri järgmisel päeval priihospidalis." ${ }^{35}$

\footnotetext{
41 “Tööliste tõrkumine Tallinnas I”, Eesti Postimees, 18.01.1905, 2.

42 “Tallinna uudised", Teataja, 19.01.1905, 3.

43 "Kuberner Bellegarde'i telegramm siseministrile", Revolyutsiya 1905-1907v Estonii. Sborbik dokumentov i materialov, 31.

44 “Tööliste tõrkumine Tallinnas III", Eesti Postimees, 24.01.1905, 1.

45 Aitsam, 1905. aasta revolutsioon ja selle ohvrid Eestis, 25.
} 
Teine traagiline kokkupõrge leidis aset juba järgmisel päeval Mayeri keemiavabriku läheduses. Töölised pidasid Lausmanni heinamaal koosoleku ning liikusid seejärel rongkäigus Mayeri vabriku poole, et seal üldstreigi ajal taasalustatud tööd seisma panna. ${ }^{46}$ Eesti Postimees andis teada, et "Mayeri vabriku ligidal leiti jällegi sõjaväge eest, mis töölisi vabrikust eemale hoida katsus; kui kõik katsed ei aitanud, siis võeti vabrikule liginevate tööliste wastu püssid tarwitusele. Selle tagajärg oli, et mitmed töölised siin surma ja haawatud saiwad. Surnud ja haawatud koristasiwad töölised ise kohe maast ära." ${ }^{\text {"47 }}$ Tallinna ringkonnakohtu prokurör kirjutas Peterburi kohtupalatisse, et kui mõnedesse tuhandetesse ulatuv rongkäik pristavi abi peatumiskäskudele ei reageerinud, siis tulistas sõjavägi 120 sammu kauguselt 24 püssist rahva suunas kolm kogupauku. ${ }^{48}$ Teataja andis teada kahest hukkunust kohapeal. ${ }^{49}$ Prokurörile oli teada, et kaks inimest on kindlasti hukkunud ja 14 inimest on haiglasse viidud. ${ }^{50}$ Mihkel Aitsam kirjutas, et kohapeal hukkus kaks inimest ning kolmas ohver suri haiglas. ${ }^{51}$ Siiski tuleb arvestada võimalusega, et hukkunute koguarv ei ole meile teada. Seda enam, et töölised olid haavatuid ja hukkunuid ise ära viinud. Viga saanud inimesed ja hukkunute lähedased võisid üritada varjata, et viga oli saadud kokkupõrkes võimudega.

Kõige ohvriterohkem sündmus leidis aset oktoobristreigi tingimustes. Kuna selle sündmuse kohta on ilmunud eraldi artikkel ${ }^{52}$, siis piirdun siinkohal ainult kõige olulisema esitamisega. Ülevenemaaline oktoobristreik jõudis 13. oktoobril Tallinnasse. 14. oktoobri õhtul pandi Tallinna tänavatel toime hulganisti korratusi. Linnavalitsus võttis tööliste esindajatega ühendust, et nad aitaksid linnas korda hoida. Töölised esitasid korra tagamiseks erinevaid nõudmisi, mille hulgas oli ka tööliste korrakaitsesalkadele tulirelvade andmine. 16. oktoobril, mil linnavolikogu tööliste nõudmiste üle aru pidas, kogunesid töölised Uuele turule, kus nad pidid oma

\footnotetext{
46 "Tallinna ringkonnakohtu prokuröri ettekanne tööliste ja sõjaväelaste kokkupõrke kohta”, Revolyutsiya 1905-1907 v Estonii. Sborbik dokumentov i materialov, 31.

47 “Tööliste tõrkumine Tallinnas III", Eesti Postimees, 24.01.1905, 1.

48 "Tallinna ringkonnakohtu prokuröri ettekanne tööliste ja sõjaväelaste kokkupõrke kohta", Revolyutsiya 1905-1907 v Estonii. Sborbik dokumentov i materialov, 31-32.

49 “Tallinna uudised", Teataja, 17.01.1905, 1.

50 “Tallinna ringkonnakohtu prokuröri ettekanne tööliste ja sõjaväelaste kokkupõrke kohta", Revolyutsiya 1905-1907 v Estonii. Sborbik dokumentov i materialov, 31-32.

51 Aitsam, 1905. aasta revolutsioon ja selle ohvrid Eestis, 26.

52 Vt Lauri Kann, “Tulistamine Tallinna Uuel turul 1905. aasta 16. oktoobril”, Tuna, 3 (2015), 90-97.
} 


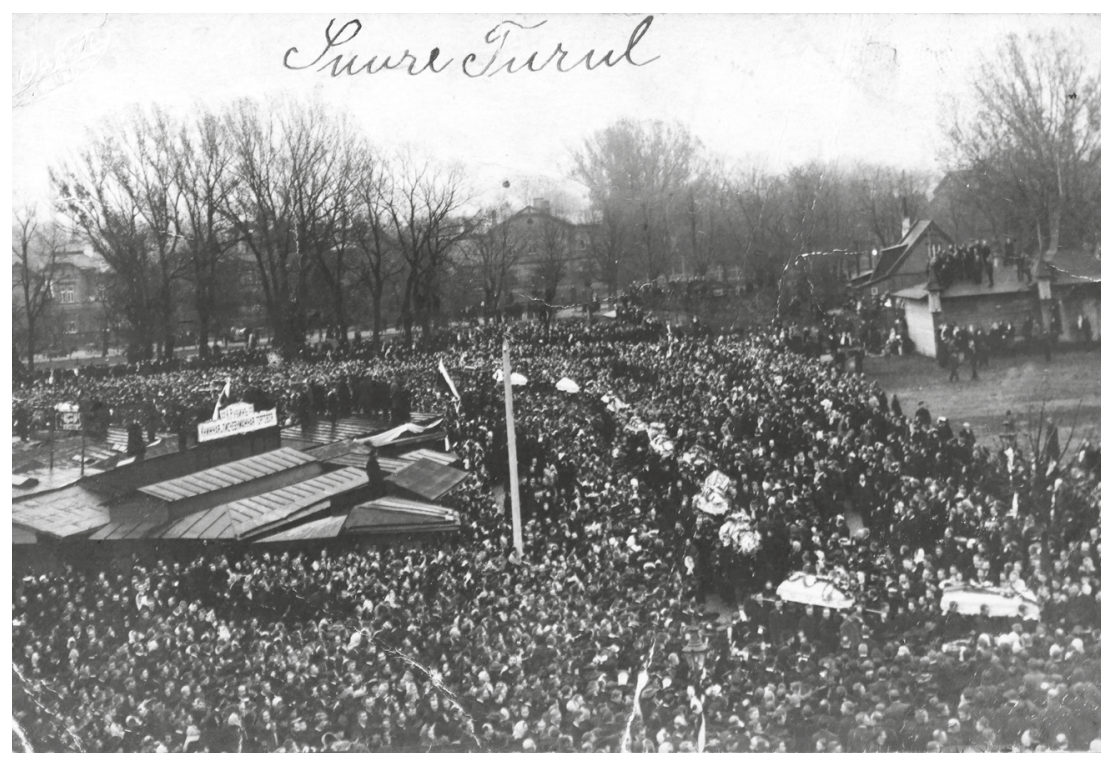

Joonis 1. 16. oktoobril 1905 Uuel turul surmasaanute matused Tallinnas 20. oktoobril 1905. RA, EFA.26.0.50504

saadikutelt kuulda saama võimude vastuse. ${ }^{53}$ Neile ootamatult saabusid turule sõdurid, kes avasid rahva pihta tule, andmata inimestele võimalust laiali minna. Eestimaa kuberner Aleksei Lopuhhin selgitas siseministrile sündmuse arenemist sellisena, et ajal, mil linnavolinikud tema kabinetis tööliste nõudmiste üle aru pidasid, teatati talle telefoni teel, et linna peal on alanud korratused. Kuberner käskis saata sõjaväelased. Seejärel saanud kuberner teada, et informatsioon korratuste kohta ei vastanud tõele, kuid sõjaväelasi tagasi kutsuda ta enam ei jõudnud..$^{54}$ 1955. aastal Hillar Saha koostatud tulistamise ohvrite arvu käsitlevas artiklis on nimeliselt tuvastatud 86 hukkunut ning teada on veel neli hukkunut, keda nimeliselt kindlaks teha ei õnnestunud..$^{55}$ 2015. aastal Tallinna Linnaarhiivi poolt välja antud linna ajalugu käsitlevas kogumikus on tulistamise ohvrite nimekiri 95 nimega. Nimekirja koostamisel on allikatena kasutatud muuhulgas ka Tallinna luteri koguduste kirikuraamatuid ning Tallinna Börsikomitee materjale. ${ }^{56}$

\footnotetext{
53 "Rahutused Tallinnas", Eesti Postimees, 19.10.1905, 2. “Tallinna uudised", Teataja, 19.10.1905, 1 .

54 Kann, "Tulistamine Tallinna Uuel turul 1905. aasta 16. oktoobril", 92-95.

55 Saha, "1905. aasta oktoobri veretöö ohvrite nimekiri", 321-325.

56 "Tallinna Uuel turul tapetud ja haavata saanud inimeste nimekiri", 425-432.
} 
Enamik 1905. aastal Eesti linnades revolutsioonisündmustes hukkunud inimestest tapeti 16. oktoobril Tallinna Uuel turul. See tõstatab küsimuse, kas tegu võis olla ühe väga õnnetu üksikjuhtumiga, mis ei esinda laiemat pilti. Selleks tuleks vaadata sündmuse laiemat konteksti ja riigivõimu reaktsiooni sellele.

Keisririigis laiemalt ei olnud rahvakoosoleku pihta tule avamine sugugi erandlik. Korduvalt juhtus seda ka Eestile suhteliselt lähedal asuvates linnades. Pärast revolutsioonile tõuke andnud verist pühapäeva Peterburis, mil Talvepaleele läheneva rongkäigu pihta tuli avati, leidis ohvriterohke rahvahulga pihta tulistamine aset ka 13. jaanuaril Riias. ${ }^{57}$ Poolas tulistati rahvahulga pihta korduvalt. ${ }^{58}$ Sealjuures sai ka kurikuulus Łódźi ülestõus 1905. aasta suvel alguse inimeste pihta tule avamisest. ${ }^{59}$ Rahva pihta tulistamine leidis aset ka näiteks oktoobris Minskis ${ }^{60}$ ja Vilniuses ${ }^{61}$. Nimetatud sündmuste asjaolud on erinevad, kuid see, et sõjavägi avas meeleavalduse pihta tule, ei olnud erandlik.

Teiseks on oluline võimude reaktsioon 16. oktoobri tulistamisele. Kuigi ohvrite arv oli väga suur ning sündmuses hukkus inimesi, kes koosolekuga kuidagi seotud ei olnud (nt juhuslikud inimesed tänaval, lapsed), ei näidanud Eestimaa kuberner Aleksei Lopuhhin üles mingisugust avalikku kahetust. Selle asemel ilmusid järgmisel päeval Tallinna linna peale teadaanded, kus inimesi ähvardati, et kui nad võimude tahte vastaselt koosolekule kogunevad, siis võib sõjavägi nende vastu ka kuulipildujaid kasutada. Avalikuks tehtud prokuratuuri raportis seisis, et koosolekulised olid ise süüdi, kuna keegi nende hulgast olevat revolvrist kümnete relvastatud sõjaväelaste pihta tule avanud. Seda vaatamata sellele, et hukkunud inimeste seast ühtegi tulirelva ei leitud ning keegi sõduritest ühegi kuulitabamust ei saanud. ${ }^{62}$

Oktoobristreik tõi kaasa inimohvriga kokkupõrke ka Tartus. 16. oktoobril toimus Tartu ülikooli aulas rahvakoosolek, kus otsustati ülevenemaalise üldstreigiga ühineda. Samal ajal riputati ülikooli akendest välja punane lipp ning sammaste vahele tõmmati valge lina, millele oli eesti ja vene keeles kirjutatud "Kadugu isevalitsus". ${ }^{63}$ Ülikooli rektor Jevgeni Passek

\footnotetext{
57 Geschichte Lettlands. 20. Jahrhundert, 59.

58 Ascher, The Revolution of 1905. Russia in Disarray, 157-158.

59 Zdrada, Historia Polski 1795-1914, 776.

60 Petr Chigrinov, Belorusskaya istoriya: nauchno-populyarnȳĭ ocherk (Minsk: Sovremennaya Shkola, 2010), 556.

61 White, "The revolution in the Baltic provinces", 69.

62 Kann, "Tulistamine Tallinna Uuel turul 1905. aasta 16. oktoobril”, 96-97.

63 "Revolutsiooni-päevad Tartus", Uudised, 22.10.1905, 1.
} 


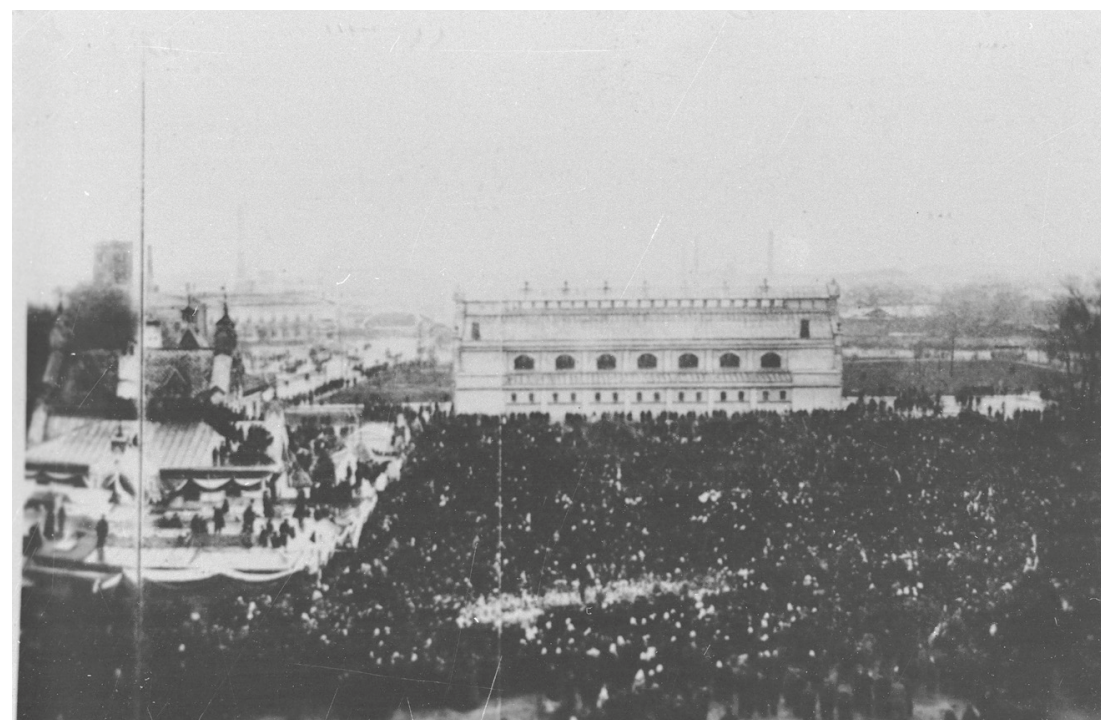

Joonis 2. 16. oktoobril hukkunute matuserong 20. oktoobril 1905. RA, EFA.270.0.47246

lubas politseivõimudele liikumist ülikoolis ohjata ning politseimeistri raporti andmetel oli seejärel punane lipp aknalt eemaldatud. Politseimeister pöördus ka kohalike sõjaväevõimude poole, kuid garnisoniülem keeldus ülikooli asjadesse sekkumast. ${ }^{64}$ Koosolek toimus ülikooli aulas ka 17. oktoobril, misjärel rahvahulk läks linna peale töötavaid ettevõtteid kinni panema ${ }^{65}$ Äärmiselt pingelisel ajal hakkas Tartus levima teade Tallinnas toimunud rahvakoosoleku pihta tulistamisest. Tänavatel levitati telegrammi, milles seisis: "Tallinnas 80 surnut, sada haavatut, viis minutit lasti kuulidega kõnepidajate kohale." Võimalik, et sellel teatel oli otsustav mõju Tartu sündmuste radikaliseerumisele. Rahvahulk liikus Raekoja platsilt Riiamäel asunud postijaama juurde. Postijaama valvasid sõdurid, toimus tulistamine ning surma sai rahva hulgas viibinud reaalkooli valvur Jaan Adamson. Ajalehe andmetel rääkisid postijaamas olnud sõdurid järgmisel päeval, et jaama oli sisse tungitud ja üritatud telefonaparaati ära viia, mistõttu puhkes kähmlus. "Algas pääletungimine ja kiwidega loopimine. /---/ Platsi pääl tuli laskmine; kes laskis, ei tea."66

\footnotetext{
64 “Tartu politseimeistri raport Liivimaa kubernerile - 24. oktoober 1905", Revolyutsiya 1905-1907v Estonii. Sborbik dokumentov i materialov, 274-275.

65 "Revolutsiooni-päevad Tartus", Uudised, 22.10.1905, 1.

66 “Tartu ärevuspäevad”, Postimees, 21.10.1905, 2.
} 
Tartu politseimeister kirjutas Liivimaa kubernerile, et postijaama juurde kogunenud rahvas viskas postijaama kividega ning rahvahulgast kõlas laske tulirelvast. Postijaama juurde saabusid kaheksa relvastatud sõjaväelast, kes tulistasid hoiatuseks õhku, mis oli rahvast hirmutanud. Kui kõlas signaal rahva poole tulistamiseks, siis lagunes rahvahulk lõplikult laiali. Jaan Adamson oli hukkunud juba toimunud laskude tagajärjel ning veel kolm inimest olid saanud kergemaid vigastusi. ${ }^{67}$ Kuigi lõplikku selgust selles küsimuses ei ole, on ilmsed siiski asjaolud, et sõdurid avasid tule ning seejärel leiti rahva hulgast surmavalt haavata saanud ohver.

1. novembril hukkus kokkupõrkes sõjaväega ka tööline Narvas.$^{68}$ Eesti Postimees kirjeldas sündmust nii: "Kreenholmi wabrikus loopisiwad töölised kiwidega sõjaväge, kes püssiodasi tarwitas. Soldatid andsiwad tuld; mõned töölised on kuulidega ja püssiodadega haawatud." ${ }^{69}$

\section{Läti ja Eesti revolutsionäärid}

Sissejuhatuses sai esile toodud, et riigivõimu kõrval olid vägivalla allikaks revolutsioonilised parteid ning et üks põhjus, miks Eestis esines ülestõusnute poolt tarvitatud vägivalda vähem kui mitmel pool mujal, peitus siinsetes parteides. Sotsialistide seostamine ülestõusnute toime pandud vägivallaga on põhjendatav ennekõike kolme asjaoluga. Esiteks oli vägivaldne võitlus kehtiva korra vastu nii ideoloogiliselt kui ka parteiprogrammi(de)s aktsepteeritud meetod. Juba Karl Marxi ja Friedrich Engelsi koostatud "Kommunistliku partei manifestis" seisab, et kommunistid "kuulutavad avalikult, et nende eesmärgid on saavutatavad ainult kogu senise ühiskonnakorra vägivaldse kukutamisega. Värisegu võimulolevad klassid kommunistliku revolutsiooni ees. ${ }^{\prime 70}$ Kogu Vene keisririigi seisukohast oli oluline, et 1905. aasta kevadel peetud VSDTP kolmandal kongressil võeti vastu otsus minna üle relvastatud ülestõusu ettevalmistamisele. ${ }^{71}$ Selleks otstarbeks kutsuti parteiorganisatsioone üles töölistele relvi hankima. ${ }^{72}$ Põhimõtteliselt pooldasid vägivalda võitlusvahendina kas otsesemalt või

67 “Tartu politseimeistri raport Liivimaa kubernerile - 24. oktoober 1905", Revolyutsiya 1905-1907 v Estonii. Sborbik dokumentov i materialov, 275-276.

68 Toomas Karjahärm, Raimo Pullat, Eesti revolutsioonitules 1905-1907 (Tallinn: Eesti Raamat, 1975), 98.

69 "Kodumaalt", Eesti Postimees, 05.11.1905, 2.

70 Karl Marx, Friedrich Engels, Kommunistliku Partei Manifest (Tallinn: Eesti Raamat, 1981), 71.

71 Ascher, The Revolution of 1905. Russia in Disarray, 189-192.

72 Toomas Karjahärm, "Sotsialistid ja terroristid 1905. aasta revolutsioonis", Tuna, 2 (2015), 39-40. 
kaudsemalt ka teised sotsialistlikud parteid. ${ }^{73}$ Teiseks panid parteilased 1905. aastal Vene keisririigis organiseeritult toime vägivaldseid tegusid ning rajasid selleks otstarbeks relvastatud võitlussalkasid. Kolmandaks kutsus sotsialistide propaganda inimesi avalikult üles relvade haaramisele. Selle poolest olid üleskutsed Lätis ja Eestis sarnased. ${ }^{74}$ Kuigi mitmed tollased parteilased väitsid, et toetades suurt koordineeritud relvastatud ülestõusu mõistsid nad samal ajal hukka individuaalset vägivalda ehk kaootilisi vägivaldseid tegusid, on seos vägivalla ja sotsialistide tegevuse vahel siiski selgelt olemas. Nagu mitmel pool mujal võtsid sotsialistid ka Lätis 1905. aasta aprillis kasutusele pommid, mis tõid kaasa inimohvreid. ${ }^{75}$ Eestist on üksikuid teated pommide valmistamisest ${ }^{76} \mathrm{kuid}$ inimohvritega pommiplahvatusi ei toimunud.

Erinevustele 1905. aastal Eestis ja Lätis toime pandud vägivallas on juhitud tähelepanu ka varem. Toivo Ülo Raun on seda Läti puhul selgitanud Riia kui "regiooni suurima, rohkem industrialiseeritud ja rahvusvahelistunud linna rolliga ning Läti enamarenenud revolutsioonilise liikumisega.” Paljurahvuselisse Riiasse jõudsid revolutsioonilised ideed varem ning leidsid seal suurema kandepinna kui Tallinnas. Samuti olid Lätis tegutsenud sotsiaaldemokraadid paremini organiseerunud kui Eestis. ${ }^{77}$ 2006. aastal ilmunud artiklis revolutsioonilise aktiivsuse kohta Balti provintsides lisas Raun eelnimetatud põhjustele ka väite, et lätlaste ja baltisakslaste suhted on ajalooliselt olnud veelgi teravamad kui suhted eestlaste ja baltisakslaste vahel. Samal ajal ta möönis, et seda väidet on väga keeruline tõestada. Mõlemas kirjutises on Raun juhtinud tähelepanu sellele, et Läti alal elas sakslasi palju rohkem kui Eesti alal ning ka see võis rahvustevaheliste suhete pingestumisel rolli mängida. 1897. aasta ülevenemaalise rahvaloenduse andmetel oli sakslasi vastavalt 9,3\% Läti ja 3,5\% Eesti elanikkonnast. ${ }^{78}$ Revolutsiooni suurem vägivaldus Lätis võrreldes Eesti ja Leeduga on leidnud kajastamist ka mujal. James White nimetab sündmuste rahumeelsema arengu põhjusena Eestis seda, et eestlaste poliitika ei olnud niivõrd

73 Kurikuulus on esseeride toime pandud vägivald. Esseeride vägivallategude kohta 1905. aastal vt nt Pavlov, Opȳt pervol̆ revolyutsii: Rossiya. 1900-1907, 346.

74 Karjahärm, "Sotsialistid ja terroristid 1905. aasta revolutsioonis", 44.

75 Lapa, "Kaujinieku kustība no pirmsākumiem līdz 1905. gada otrajai pusei”, 406-407.

76 Karjahärm, "Sotsialistid ja terroristid 1905. aasta revolutsioonis II", 41.

77 Toivo Ü. Raun, “1905. aasta revolutsioon Balti provintsides ja Soomes”, Tuna, 1 (2005), 39.

78 Raun, "Vägivald ja revolutsiooniline aktiivsus Balti provintsides 1905. aastal”, 105, 110; Raun, "1905. aasta revolutsioon Balti provintsides ja Soomes", 34; Toivo Ü. Raun, "Violence and activism in the Baltic provinces during the revolution of 1905", Acta Historica Tallinnensia, 10 (2006), 48-59. 
radikaalne ning võttis pigem liberaalse kui sotsialistliku suuna. Muuhulgas seostab ta seda Jaan Tõnissoni ja Postimehe mõjuga ühiskonnale. ${ }^{79}$

Lätis oli sotsialistlik liikumine saanud tõepoolest suurema hoo sisse mõnevõrra varem kui Eestis. Paljurahvuselises Riias olid revolutsioonilised organisatsioonid mõjukamaks kujunenud kui Eesti suurimas tööstuskeskuses Tallinnas. Olulist rolli läti tööliskonna jaoks mängis liikumine Uus Vool (Jaunā Strāva), mille 1886. aastast ilmunud ajaleht Dienas Lapa 1890. aastatel Rainise (Jānis Pliekšāns) eestvedamisel sotsialistlikuma suunitluse võttis. ${ }^{80} 1897$. aastal vangistati lehe juures juhtrolli mänginud Rainis ja Pēteris Stučka, ${ }^{81}$ kuid ajalehe mõju sotsialistlike ideede levikul oli olnud märkimisväärne. Ilgvars Butulis on Dienas Lapa 1893.-97. aasta numbreid analüüsides välja toonud, et ajalehes levitati vabariigi ideed, tutvustati Euroopa sotsiaaldemokraatlikke parteisid ja nende juhte ning rõhutati, et revolutsiooniline võitlus saab edukas olla vaid sotsiaaldemokraatliku partei juhtimisel. Sealjuures nimetab Butulis Jaunā Strāva liikumist 1905. aasta revolutsiooni ideoloogiliseks ja vaimseks ettevalmistajaks Lätis. ${ }^{82}$

Pärast 1897. aastat hoogustus lätikeelse sotsialistliku kirjanduse väljaandmine emigratsioonis. 1899. aastal asutati Riias sotsiaaldemokraatlik rühmitus ning järgnevatel aastatel asutati rühmitused ka Liepajas, Ventspilsis ja Talsis. Läti Sotsiaaldemokraatlik Töölispartei loodi mitmetest sotsialistlikest ühendustest 1904. aasta juunis. Partei programm tugines Saksa sotsiaaldemokraatide Erfurti programmile ning selles oli 14 punkti poliitiliste eesmärkidega (nt demokraatlikud vabadused ja vabariiklik riigikorraldus) ning 16 punkti sotsiaalsete eesmärkidega (nt kaheksatunnine tööpäev). Kuigi LSDTP-l puudus agraarprogramm ning ta jäi rahvusküsimustes tagasihoidlikuks, pidades ülevenemaalist proletaarset revolutsiooni rahvusküsimustest olulisemaks, oli partei mõjukas ka maaelanikkonna seas.$^{83}$ Lilita Vanaga on kirjutanud, et LSDTP agitatsiooni edukusel maaelanikkonna seas mängis rolli asjaolu, et parteilased suundusid tegema agitatsioonitööd oma kodukohta, kus neid juba tunti ning kus nende tegevus

\footnotetext{
79 White, "The revolution in the Baltic provinces", 64, 75.

80 Russification in the Baltic Provinces and Finland, ed. by E. Thaden (Princeton: Princeton University Press, 1981), 258.

81 Historical Dictionary of Latvia. Third Edition, ed. by A. Purs, A. Plakans (Maryland: Rowman and Littlefield, 2017), 90.

82 Ilgvars Butulis, "Jaunā strāva un 1905. gada revolūcija Latvijā", 1905. gads Latvijā: 10o. Pètījumi un starptautiskas konferences materiāli, 2005. gada 11.-12. janvāris, Rīga (Rìga: Latvijas vēstures institūta apgāds, 2006), 207.

83 Ilga Apine, 1905.-1907. gada revolūcija Latvijä un latviešu sociāldemokrāti (Rīga: Zelta grauds, 2005), 13-15.
} 
leidis suuremat kandepinda.$^{84}$ LSDTP mõjukus maal mängis ilmselt rolli selles, et vägivaldne võitlus haaras suure osa maapiirkondadest. Šveitsis olid läti emigrandid 1903. aastal loonud Läti Sotsiaaldemokraatliku Ühingu ${ }^{85}$, mis jõudis koguni iseseisva Läti riigi ideeni, kuid LSDTÜ mõju oli LSDTPga võrreldes tagasihoidlikum. ${ }^{86}$

Riias tegutses ka Venemaa Sotsiaaldemokraatliku Töölispartei organisatsioon. ${ }^{87}$ Lisaks sellele oli ka teistel rahvustel Lätis sotsiaaldemokraatlikke ühendusi, millest olulisemaks kujunes juutide Bund.$^{88}$ Erinevate sotsialistlike organisatsioonide tegevuse ühendamiseks moodustati 1904. aastal Riia Föderatiivne Komitee. Mõjukamaks kujunesid selles komitees Läti Sotsiaaldemokraatlik Töölispartei ja Bund.

Eestis 1901. aastal ilmuma hakanud Teatajat võib pidada küll tööliskonnale suunatud väljaandeks, kuid esimene sotsiaaldemokraatlik ajaleht oli siiski 1903. aastast ilmunud Uudised. Samal aastal tekkis ka VSDTP Tartu grupp ${ }^{89}$ Esimene Venemaa Sotsiaaldemokraatliku Töölispartei komitee Eestis kujunes välja Tallinnas ning ajalookirjutuses laialt levinud versiooni järgi toimus see 1904. aasta lõpul, Kaido Jaansoni hinnangul võis see aga tegelikult toimuda alles 1905. aasta alguses. Nõukogude ajalookirjutuse järgi oli Tallinna tööliste organiseerimisel oluline roll 1901.-04. aastal Volta vabrikus töötanud Mihhail Kalininil, kuid kuna Kalininist sai hiljem Nõukogude Liidu riigipea, siis on suure tõenäosusega tema rolli tagantjärele suurendatud. ${ }^{90}$ Enamlane Jaan Anvelt kirjutas oma käsitluses sotsiaaldemokraatlike organisatsioonide kohta Eestis, et 1905. aasta alguses oli VSDTP-l vaid Tallinnas välja kujunenud organisatsioon, "mis enam või vähem tööliste hulkadest välja kasvanud ja nendega ühenduses seisab.

\footnotetext{
84 Lilita Vanaga, "Ieskats Latvijas pagastu sabiedrības etnopsihologiskajā raksturojumā 1905. gada revolūcijas laikā”, 1905. gads Latvijā: 100. Pētījumi un starptautiskas konferences materiāli, 2005. gada 11.-12. janvāris, Rìga (Rīga: Latvijas vēstures institūta apgāds, 2006), 551.

85 Geschichte Lettlands. 20. Jahrhundert, 56-57.

86 Russification in the Baltic Provinces and Finland, 262.

87 Raun, "Vägivald ja revolutsiooniline aktiivsus Balti provintsides 1905. aastal", 104-105.

88 Geschichte Lettlands. 20. Jahrhundert, 57.

89 Eesti NSV ajalugu. 2. kd. XIX sajandi 50-ndaist aastaist kuni 1917. aasta märtsini, peatoim Joosep Saat (Tallinn: Eesti Riiklik Kirjastus, 1963), 349. Nõukogude ajalookirjutuse andmetesse VSDTP gruppide tegevuse ja mõju kohta tuleb suhtuda ettevaatusega. Siiski on VSDTP Tartu grupi kujunemine 20. sajandi esimestel aastatel igati tõenäoline. 90 Kaido Jaanson, "Algus ehk see nõndanimetatud Esimene vene revolutsioon. Skits", Tuna, 1 (2005), 45-46.
} 
Kuid liikumist juba kevadel juhtida ei suuda ta ka siin veel mitte."91 VSDTP mõju suurenes märgatavalt aasta jooksul, millest annavad kinnitust ka ametivõimude dokumendid, ${ }^{92}$ kuid võrreldes Läti sotsiaaldemokraatide organisatsioonidega oli ta siiski nõrgem. Organisatsioonile põhjustas suuri raskusi ka võimude vastutegevus. Suvel õnnestus võimudel vahistada osa VSDTP Tallinna komiteest. Seejärel pidi komitee täienema ka Tallinna olusid tagasihoidlikumalt tundnud mujalt saabunud liikmetega. Ulatuslik arreteerimine tabas komiteed ka detsembris. ${ }^{93}$ Kui Riias oli sotsialistikke parteisid mitu, siis Tallinnas VSDTP kõrvale mingit teist sotsialistlikku organisatsiooni üldse ei kujunenud. VSDTP oli esindatud ka mõningates teistes Eesti linnades, kuid neis oli tema organisatsioon nõrgem. Eesti Sotsiaaldemokraatlik Tööliste Ühisus kujunes 1905. aasta jooksul Tartus ning tema mõju Tallinnas oli tagasihoidlik.

Ainsaks suuremaks vägivaldseks ülestõusuks Eestis oli mõisate rüüstamine detsembris. Tegevus lähtus Tallinnast maale liikunud salkadest, kuid maal liitus nendega ka kohalikke inimesi. Kuigi paljud parteilased tagantjärele ennast mõisate põletamisest distantseerisid, oli mõisate rüüstamise laine puhkemisel siiski parteilaste käsi mängus. 11. detsembril pidi Tallinnas toimuma valdade saadikute koosolek, et arutada keskvõimu poolt kavas olevat omavalitusreformi, kuid väljakuulutatud sõjaseisukorra tingimustes keelati see koosolek ära. Vahetult enne seda olid võimud arreteerinud suure osa VSDTP Tallinna komiteest. Arreteerimisest pääsenud parteilased juhatasid Tallinnasse saabunud maasaadikud aga teisele koosolekule, mis peeti Volta tehase ruumides. Võimud ajasid koosoleku enne lõppu laiali ja andmed päevakorra kohta on väga vastakad, kuid mõningate mälestuste järgi jõuti sellel koosolekul arutada mõisate ründamist. ${ }^{94}$ Igal juhul läksid samal õhtul tööliste salgad maale. Ka mõisaid rüüstanud salkasid arvesse võttes võib siiski öelda, et Eestis ei olnud 1905. aastal selliseid võitlusgruppe, mille tegevust saaks ulatuselt kõrvutada Lätis moodustatud võitlusgruppidega. Voldemar Juhandi uurimuse järgi läks Tallinnast

\footnotetext{
91 Jaan Anvelt, "1905. aasta revolutsioonilisest liikumisest Eestis”, Valitud teosed 4. köide (Tallinn: Eesti Raamat, 1987), 142.

92 Kann, "Tulistamine Tallinna Uuel turul 1905. aasta 16. oktoobril”, 92.

93 Jaanson, "Algus ehk see nõndanimetatud Esimene vene revolutsioon. Skits", 48-49, 63.

94 Kaido Jaanson, “Mis juhtus 1905. aasta 11. (24.) detsembri õhtul Voltas? Katse rekonstrueerida minevikku”, Tuna, 4 (2005).
} 
välja mõisaid rüüstama 100-150 meest. ${ }^{95}$ Lätis hõlmasid ülestõusnute võitlusgrupid aga sadu ning koguni tuhandeid inimesi. ${ }^{96}$

Eesti sotsialistide hulgas oli neid, kes soovisid Eestis suurt relvastatud ülestõusu korraldada, kuid selleks puudusid ressursid, mistõttu peatähelepanu suunati muudele tegevustele. Parteilaste võitlustaktikat käsitlevas artiklis kirjutab Toomas Karjahärm eesti sotsialistide kavade kohta relvastatud ülestõusu korraldada, et "küsimus ei olnud tahtmise puudumises (tahtmine oli), vaid hoopis tingimuste ja ressursside puudumises võitluses ülekaaluka vastasega. Peamine oli sobivate meeste-löökrühmlaste ja relvade nappus." ${ }^{" 7}$

\section{Repressioonide mõju sündmustele}

Vene keisririigis puudus ühtne strateegia vägivalla kasutamiseks võimuvastaste aktsioonidega võitlemisel. Õiguslikult tugineti muuhulgas 1881. aasta regulatsioonidele, mis jätsid korra tagamise suuresti kuberneride pädevusse. Abraham Ascher on toonud välja kolm näidet selle kohta, kui erinevalt eri piirkondade (Saratov, Poltaava, Peterburi) kubernerid seda võimu kasutasid. Ascher ei ole pretendeerinud üldisusele, milline viis oli tõhusaim, kuid on rõhutanud, et kubernerid võisid toimida väga erinevalt. ${ }^{98}$

Teisest küljest tuleb arvestada sellega, et kuigi ühtne strateegia puudus, siis keskvõim (eesotsas keiser Nikolai II, aga ka peaminister Sergei Witte ja eriti siseminister Pjotr Durnovoga) toetas n-ö kõva käe poliitikat. Keskvõim nimetas kubernerid ja kindralkubernerid ametisse, avaldas neile korra tagamise küsimuses survet ja andis vastavalt oma äranägemisele tegevussuuniseid. Samuti saatis keskvõim riigi erinevatesse piirkondadesse karistussalku ning kuulutas välja sõjaseisukordi.

Riigivõimul läks korda vägivalla abil 1905. aasta lõpul ja 1906. aasta alguses revolutsioon maha suruda. Samas kinnitavad revolutsioonisündmused, et riigivõimu poolt toime pandud vägivallal oli oma osa poliitilise olukorra radikaliseerumisel. Revolutsioonile andis hoogu meeleavaldajate pihta tulistamine Peterburis 9. jaanuaril $1905 .{ }^{99}$ Üks oluline aspekt, millele

\footnotetext{
95 Toomas Karjahärm, 1905. aasta Eestis. Massiliikumine ja vägivald maal (Tallinn, 2013), 131-139.

96 Geschichte Lettlands. 20. Jahrhundert, 63.

97 Karjahärm, "Sotsialistid ja terroristid 1905. aasta revolutsioonis", 42.

98 Ascher, The Revolution of 1905. Russia in Disarray, 108-109.

99 Irina Pushkareva, "Krovavoe voskresen'e. Nachalo revolyutsii", Pervaya revolyutsiya $v$ Rossii. Vzglyad cherez stoletie, ed. by A. Korelin, S. Tyutyukin (Moskva: Pamyatniki istoricheskoû mȳsli, 2005), 180-182.
} 
ei ole Eesti ja Läti sündmusi omavahel võrreldes tähelepanu osutatud, kuid mis võis sündmuste edasisel kujunemisel olulist rolli mängida, oli revolutsiooni vägivaldsem algus Lätis. Riias toimus juba 1905. aasta alguses kümneid inimelusid nõudnud kokkupõrge võimude ja meeleavaldajate vahel. 13. jaanuaril liikusid tuhanded meeleavaldajad Riias punalippude ja revolutsiooniliste laulude saatel Moskva tänavat mööda praeguse raudteesilla lähedale Daugava jõe ääres. Kohale saadetud sõjaväelastega tekkis kokkupõrge ning sõjavägi tulistas meeleavaldajaid. Paljud inimesed üritasid tulistamise eest pääseda Daugava jõele põgenedes, kuid vajusid läbi jää. Hukkus üle 70 inimese.$^{100}$ Läti ajalookirjutuses on revolutsiooni laienemist teistesse Läti linnadesse seostatud otseselt Riias aset leidnud sündmusega. Sealjuures on valitsenud meeleolu iseloomustamiseks esile tõstetud, et just neil päevil kirjutas läti poeet Janis Akuraters revolutsiooni hümniks saanud laulu teksti, milles kutsuti üles osa võtma "verevõitlusest" ning kus lubati "losside langemist ja troonide kukkumist". ${ }^{101}$ Aivars Stranga sõnade järgi radikaliseerus poliitiline situatsioon Lätis nii 9. kui ka 13. jaanuari sündmuste järel "dramaatiliselt". Stranga on seostanud ka aprilli lõpus alguse saanud pommide panemist Riias nende sündmuste järelmõjudega. ${ }^{102}$

Eestis möödusid kuni 1905. aasta 16. oktoobrini sündmused võrreldes Lätiga suhteliselt rahumeelselt. Uue turu veretööle järgnes kahtlemata poliitilise olukorra radikaliseerumine. VSDTP Tallinna komitee mõjukas liige Aleksander Kesküla kutsus Uue turu tulistamise järel parteilasi üles valitsuse vägivallale sõjariistadega vastu hakkama. ${ }^{103} \mathrm{Ka}$ Tartus muutusid sündmused tormilisemaks, kui linnas levitati teadet Tallinnas päev varem toimunud tulistamisest. ${ }^{104}$ Novembri lõpus Tartus peetud üle-eestilisel rahvasaadikute koosolekul ärgitati valitsuse vastu "kõikide abinõudega võitlema"105 ning detsembris toimus mõisate rüüstamine. Sügisel Eestis aset leidnud sündmuste puhul tuleb arvestada siiski ka sellega, et 17. oktoobri keisri manifestile järgnes kogu riigis ennenägematute poliitiliste vabaduste aeg ning hilissügis oli nii või teisiti revolutsiooni kõrgajaks nii Eestis ja Lätis kui ka keisririigis laiemalt. Siiski võib küsida, kas asjaolu, et juba

\footnotetext{
100 20. gadsimta latvijas vesture I. Latvija no gadsimta sākuma lìdz neatkarības pasludināšanai 1900-1918, ed. by V. Bērziņš. (Rīga: Latvijas vēstures institūta apgāds, 2000), 338-339.

101 Geschichte Lettlands. 20. Jahrhundert, 59.

102 Aivars Stranga, "Pārdomas par 1905. gada revolūciju", 1905. gads Latvijā: 10o. Pètījumi un starptautiskas konferences materiāli, 2005. gada 11.-12. janvāris, Rìga (Rīga: Latvijas vēstures institūta apgāds, 2006), 573-574, 583.

103 Karjahärm, 1905. aasta Eestis. Massiliikumine ja vägivald maal, 132.

104 “Tartu ärevuspäevad”, Postimees, 21.10.1905, 2.

105 Karjahärm, 1905. aasta Eestis. Massiliikumine ja vägivald maal, 125.
} 
1905. aasta jaanuaris tappis riigivõim Riia kesklinnas kümneid meeleavaldajaid, mõjutas seda, et ülestõus Lätis kujunes ohvriterohkemaks kui Eestis.

\section{Tallinna linnavõim ja vägivald}

Teine asjaolu, millele ei ole Eesti sündmuste vägivallatuma arengu põhjuste otsimisel tähelepanu osutatud, on Tallinna linnavõimu tegevus. Tallinnas olid 1904. aasta linnavolikogu valimised võitnud eestlased. Seevastu Riias oli linnavõim jätkuvalt sakslaste käes. Erinevalt seni linna juhtinud sakslastest positsioneeris uus linnavõim ennast vaesema linnarahva huvide esindajana. Eestlased olid valimistel lubanud jagada linnakassa vahendeid nii, et sotsiaalhoolekanne, haridus ja heakord jõuaksid ka äärelinnadesse. ${ }^{106}$ Ilmselt oli Tallinna tööliskonna jaoks vaesemale linnarahvale orienteeritud linnavõimuga lihtsam kokkuleppele jõuda. Eesti tööliste jaoks võis linnavõimu autoriteedi juures väga olulist rolli mängida asjaolu, et esmakordselt olid Tallinna linna pääsenud juhtima eestlased.

Vaadates Tallinna linnavõimu tegevust aasta jooksul on näha, et linnavõim üritas korduvalt streikivate töölistega läbi rääkida ning laveeris keskvõimu ja tööliskonna vahel. Linnavõimu uurimiskomisjon, mis loodi jaanuaristreigi põhjuste väljaselgitamiseks, põhjendas streiki muuhulgas ka tööliste erakordselt raske majandusliku olukorraga. ${ }^{107}$ Ühtlasi tegi linnavõim juba jaanuaris tööliste esindajatega koostööd linnas korra tagamisel. 14. oktoobri rahutuste järel vahendasid linnavolinikud kokkuleppe sõlmimist kuberneriga, mille alusel pidid töölised korra tagamise linnas enda õlule võtma. ${ }^{108} 16$. oktoobri tulistamise järel võttis Tallinna linnavõim kuberner Lopuhhini vastase positsiooni. Linnavolikogu erakorralise koosoleku otsuses nõuti mõrtsukatöö uurimist ning rõhutati, et turul tapeti süütuid inimesi, kes olid aidanud linnas korda tagada. ${ }^{109}$ Abilinnapea oli Konstantin Päts, kes toimetas töölistele suunatud ajalehte, ning linnavolinikuna tegutses Jaan Teemant, kes novembris juhatas Tartus radikaalset aulakoosolekut. ${ }^{110}$ Seetõttu oli aasta lõpuks kujunenud võimudel ekslik arusaam, et mõned eestlastest linnavõimu esindajad olidki ühed

\footnotetext{
106 Hiljar Tammela, Lauri Kann, "Valimisvõitlus aastatel 1877-1905", Tallinna ajalugu III 1710-1917, peatoim Tiina Kala (Tallinn: Tallinna Linnaarhiiv, 2019), 89-9o.

107 "Tallinna linnavolikogu komisjoni raport streigi põhjustest", Revolyutsiya 1905-1907 $v$ Estonii. Sborbik dokumentov i materialov, 43.

108 "Rahutused Tallinnas", Eesti Postimees, 19.10.1905, 2.

109 Kann, “Tulistamine Tallinna Uuel turul 1905. aasta 16. oktoobril”, 96.

110 Karjahärm, "1905. aasta revolutsioon", 352, 358.
} 
revolutsioonilise liikumise juhid Tallinnas. ${ }^{111}$ Kui sõjaseisukord Tallinnas välja kuulutati, siis tagandati eestlased linnavõimu teostamise juurest ning mõned neist pagesid surmaotsuse eest välismaale. ${ }^{112}$ Tallinna linna ja tööliskonna suhted 1905. aastal nõuavad kahtlemata põhjalikumat uurimist, kuid on ilmseid näiteid, kus linnavõim ei vastandanud ennast tööliste liikumisele, vaid üritas sellega kompromisse saavutada.

\section{Kokkuvõte}

1905. aasta ülestõusu Eestis ei saa pidada veriseks selles mõttes, et ülestõusnud - olgu nendeks mõne revolutsioonilise partei tegelased või rahvahulgad - oleksid tapnud palju inimesi. 1905. aasta revolutsiooni muutis veriseks riigivõimu poolt toime pandud vägivald. Eesti linnades on 1905. aastast teada vähemalt 102 revolutsioonisündmuste ohvrit ning karistussalgad tapsid aasta lõpus ja sellele järgnenud aastal veelgi enam inimesi. Asjaolu, et peaaegu kõik inimelu kaotusega lõppenud vägivallateod pani 1905. aastal Eestis toime riigivõim, ei ole varasemalt ajalookirjutuses esile tõstetud.

Lisaks inimohvreid kaasa toonud sündmustele oli 1905. aastal ka selliseid kokkupõrkeid, kus inimesed küll ei hukkunud, kuid said vigastada. Inimohvrite arv ei näita seda, kui palju esines kehavigastustega lõppenud vägivalda. Seega ei ole võimalik ohvrite arvu järgi üheselt öelda, kui palju kasutasid vägivalda ülestõusnud ja kui palju riigivõim. Küll aga võib inimohvritega kokkupõrgete põhjal tõdeda, et riigivõim kasutas vägivalda traagilisemate tagajärgedega. Samuti ilmneb sündmuste asjaoludest, et võimud kasutasid surmavat vägivalda ka olukordades, kus see ei olnud hädavajalik enda või teiste elude vahetuks kaitsmiseks.

Eestis toimunud sündmused aitavad mõista Vene keisririigis aset leidnud protsesse laiemalt. Mitmetes piirkondades, nagu Lätis või Poolas, tapsid nii ülestõusnud kui ka võimud palju inimesi. Eesti näite abil võiks seada kahtluse alla võimaluse, et riigivõimu vägivalda saaks põhjendada kui proportsionaalset vastureaktsiooni ülestõusnute tegevusele. Riigivõimu toimepandud vägivalla ajendiks Eestis ei saanud kuidagi olla see, et vägivalla kasutamine oleks olnud möödapääsmatu vahend ohvriterohke ülestõusu peatamiseks. Omaette küsimus on see, millest oli Eestis toimepandud vägivald tingitud. Kas see näitab lihtsalt riigivõimu hoolimatut suhtumist inimelusse, mis pidas põhjendatuks surmava vägivalla kasutamist

111 Karjahärm, Ida ja lääne vahel. Eesti-vene suhted 1850-1917, 107.

112 Lauri Kann, “1905. aasta Pärnus. Streik, poliitika ja vägivald”, Tuna, 3 (2017), 54. 
olukorras, kus see ei olnud elude kaitseks hädavajalik? Võimalik, et see näitab ka riigivõimu vähest mõistmist oma territooriumil toimuva suhtes. Liivimaa kubermangu eesti- ja lätikeelse elanikkonnaga osasid võidi vaadata ülestõusu seisukohast ühtse tervikuna, kuigi ülestõusuga kaasnenud vägivald oli neis piirkondades väga erinev. Siinkohal tuleb arvestada siiski sellega, et Eestimaa kubermangus tervikuna oli inimohvritega vägivald äärmiselt ühepoolne. Riigivõimu tegevuse mõistmine nõuab kindlasti põhjalikumat uurimistööd Venemaa arhiivides. Hetke seisuga saab kinnitada vaid seda, milliseks kujunes selle tegevuse tulemus kohapeal, siinses käsitluses Eesti alal.

Revolutsiooni arengu seisukohast on oluline küsida, kuidas mõjutas riigivõimu poolt toime pandud vägivald sündmuste edasist arengut. Revolutsioonisündmused annavad alust arvata, et kuigi riigivõimul õnnestus lõpuks jõuga revolutsioon maha suruda, siis riigivõimu vägivald mõjus kohati ülestõusu radikaliseerivalt. Ülestõus Lätis võis olla vägivaldsem kui Eestis osaliselt seetõttu, et riigivõim tappis juba aasta alguses Riias palju inimesi. Mõisate rüüstamine Eestis võis puhkeda osaliselt seetõttu, et rahva pihta tulistamine 1905. aasta 16. oktoobril Tallinnas oli aidanud kaasa meeleolude radikaliseerumisele. Milline oli riigivõimu teostatud vägivalla roll ühiskondliku liikumise radikaliseerumisel, on oluline küsimus Vene keisririigi kontekstis laiemalt. Vastuse saamiseks tuleks võrdlevalt analüüsida keisririigi eri piirkondades aset leidnud sündmusi.

\section{AвSTRACT: Revolutionary events with casualties in Estonian towns in 1905}

The Revolution of 1905 had an enormous impact on many nations in the Russian Empire. In order to study the society of the Russian Empire during the Revolution of 1905, many aspects need to be considered. Besides political and social changes, it is also important to study how and why violence occurred during the Revolution.

Violence had many sources in the Revolution of 1905 in the Russian Empire. One such source was the revolutionary political parties, which saw acts of violence as a means for realising their political agenda. Revolutionary parties formed armed groups, which attacked the authorities and other people. Bombs exploded in many places. Revolutionaries also 
gave speeches and printed various texts calling upon the masses to engage in violence against the authorities. The authorities also used violence in situations where it was unnecessary for defending themselves or protecting the lives of others. On many occasions, soldiers opened fire on political demonstrations or crowds of strikers. Although the authorities finally managed to supress the Revolution using violence, it is also evident that during the Revolution, the use of violence by the authorities played a role in the radicalisation of the revolutionary movement. It is well known that the shooting of demonstrators in St Petersburg on 9 January 1905 became a catalyst for the Revolution. Later, similar events took place in many parts of the Russian Empire.

In many areas of the Empire (Poland, Latvia, etc.), large numbers of people were killed by the authorities and by the people participating in the revolutionary movement. This study reveals that almost all of the people who were killed during the Revolution of 1905 in Estonia died at the hands of the authorities. There were 102 known victims of the Revolution in Estonian towns, and all of them were killed by the authorities. Most of them died on 16 October when soldiers opened fire on a peaceful workers' demonstration in Tallinn. There was a total of five revolutionary events in Estonian towns where people were killed. Three of them took place in Tallinn, one in Tartu and one in Narva. All five events took place during workers' strikes. Events in the countryside need to be investigated more thoroughly, but as far as is known, it seems to have been extremely rare for revolutionaries or participants in uprisings to kill anyone in the countryside as well. We know with certainty that only one German landlord (Arthur von Baranoff) was killed in Estonia in 1905. The punitive squads that were sent to Estonia by the authorities in December of 1905 killed hundreds of people. So although the events in the countryside need further research in order to obtain more reliable data, it is clear that most of the victims of the Revolution of 1905 in the countryside were killed by the authorities.

It is exceedingly difficult to point out exactly why the revolutionary movement in Estonia was less violent than in many other areas of the Russian Empire. Estonia and Latvia were in a relatively similar political situation, but the Revolution became much more violent in Latvia. This may be due to the fact that the socialist movement was not as widespread in Estonia as it was in Latvia. Socialist organisations in Estonia were also weaker than in Latvia. An event already occurred on 13 January in Riga in which soldiers opened fire on a crowd of people. It is possible that this contributed to the early radicalisation of the revolutionary movement in 
Latvia. Tallinn's City Council may also have played an important role in keeping the peace. Estonians had won election to the City Council of Tallinn for the first time in 1904. It is likely that Estonian workers found it easier to communicate with the Tallinn's municipal government than Riga workers with their local city government that was still dominated by Germans. Tallinn's municipal government did not position itself against the workers' movement and in some cases tried to work together with the representatives of the workers. It is possible that this also played an important role in revolutionary events in Tallinn.

KEYWORDS: Revolution of 1905; Russian Empire; Estonia; urban history

LAURI KANN is a PhD student at the Institute of History and Archaeology, University of Tartu.*

* Correspondence: Institute of History and Archaeology, University of Tartu, Jakobi 2, 51005 Tartu, Estonia. E-mail: lauri.kann@ut.ee 